\title{
活性污泥法に一処理した染色廃水の 活性炭生物膜法による高度処理に関する研究
}

\author{
李雷*省善臣**姜振 泉 ${ }^{*}$
}

\begin{abstract}
In the treatment of textile dyeing wastewater, the biochemical process is commonly used. However, as the increase of water-soluble dyes, surfactans and chemical pulp, and higher demand for decolorizing, the conventional biochemical processes have been found not so efficient. In this study, the biofil immobilized onto activated carvon was used to take a further treatment of the texile dyeing wastewater treated previously by the activated sludge process. The CODcr of treated wastewater was less than $50 \mathrm{mg} / \ell$ and the colority was less than 4.5 . Thus the treated water can be recovered and reused.
\end{abstract}

概 要

染色廃水の処理は生物化学的方法が多く採用されてきたが, 近年, 新たな染色技術の導入によって, 染色廃水の 化学成分が量も種類も増加になっている。一方, 環境保全の規制基準も強化されている.この背景には, 従来の生 化学処理法が効率的な処理効果を発揮することが難しくなったことがある. 本研究では, 実験より染色廃水の高度 処理に対する活性炭生物膜法の効率性を考察し，それぞれの因子の処理効果に及ぼす影響を実験的に究明し，その 処理機構を検討したものである.

\section{1.はじめに}

産業廃水の中で, 染色廃水がかなり高い割合を占めて いる. 中国の場合は, 中型染物工場 1 ケ所に当り，廃水 排出量が約千トンまで広範囲にわたっている現状である.

染色廃水の特色としては,

(1) C O D高, 色度高, 水質成分が複雑である。 (2)水 量, 水質の経時的変動が高い. (3)廃水に微量の染料が 含まれていても，廃水の色度がかなり高くなる。

なよ゙である，その有効的な処理は，地球環境を保全し， 当産業の発展を支える上で極めて重要なものである。

染色廃水の処理は, 一般的に生物酸化法, 化学酸化 法, 吸着法, 凝集沈澱法, 逆浸透法などが多く採用され てきたが, 中国の紡織業産業廃水の処理は生物化学法が 多く採用されている，近年，技術革新などに伴い，製品 の品質を高度化し, 品種を多くさせると同時に, 廃水中

* 中国鉱業大学 Li LEI, Jiang ZHENQUAN

**中国徐州色織総工場 Cui SHANCHEN
の水溶性染料, 活性染料および化学染料などの含有量と 種類む増加になってきた。このため, 染色廃水の可生化 性が降下し, 従来の処理法の処理効果が低下している.

そこで, 染色廃水の処理効果をあげ，長期安定運転 を可能にさせるため, 効率的な処理方法を探索するこ とが緊急な課題となっている.

固定化細胞技術が1960年代に開発されて以来, 食品, 医学，化学などの部門にわたる広分野に応用されるよ うになった，それに基づいて，1970年代に産業廃水処 理に対して活性炭生物膜法が開発されていた1).

活性炭生物膜か汼理吸着作用之生物分解作用よりも廃 水中の有機物を効率的に除去することができるため，有機 物を含む産業廃水処理は多く適用されている. Ehrhardt らは活性炭でCandide SP と Psendomonus SP を固 定してフェノール分解研究を行って, フェノール濃度 15 $\mathrm{g} / \ell$ の場合, 分解率が $90 \%$ に達したと報告している ${ }^{2)}$. 活性炭生物膜法の適用条件および産業廃水处理に対 する実用効果を探求するために，筆者らは活性炭微生 
物法により徐州市某染物工場の染色廃水を高度処理す るシミュレーション実験, および中型実験を行った。 本文では，この研究結果について報告する.

\section{2. 廃 水 水 質}

\section{1 廃水の排出量}

同工場は中規模の染色工場で, 廃水処理量 $700 \mathrm{~m}^{3} / \mathrm{d}$, 染色廃水排水量が間歇・不安定で, 製品の種類と生産 工程によって変動する代表的な工場である。

\section{2 染色廃水の水質}

同工場において, 生産には主として硫化類分散類, 土林類, 活性類, ナフトール類などの染料が用いられ ている. 廃水水質が製品の種類と生産工程の相違によっ て変動しているもので, 本回の研究において, 原水は 総合染物廃水でその水質を表 1 に示している。

\section{3. 廃水処理工程}

同工場では，従来用いられる染色廃水処理装置が活 性污泥法完全混合曝気槽である。今回中型実験に採用 された生物活性炭塔がそれと連接されて, そのフロー シートが図ー 1 である。

\section{4. 廃水処理シミュレーション実験}

\section{1 実験材料と方法}

4. 1. 1 細菌の分離と鑑定

実験に用いた菌泥は同工場の染色廃水中の活性污泥 から採集したものである．その菌泥を富集培養基に培 養してから, 希釈塗布および画線より単一菌群に分離し

表 1 原 水 水 質

\begin{tabular}{|c|c|c|}
\hline 項 目 & 範 囲 値 & 平均値 \\
\hline $\mathrm{pH}$ & $7 \sim 11$ & 9.5 \\
\hline $\mathrm{COD}_{\mathrm{x}}(\mathrm{mg} / \ell)$ & $250 \sim 900$ & 480 \\
\hline $\mathrm{BOD}_{5}(\mathrm{mg} / \mathrm{l})$ & $100 \sim 380$ & 200 \\
\hline $\mathrm{SS} \quad(\mathrm{mg} / \ell)$ & $30 \sim 300$ & 180 \\
\hline $\mathrm{S}^{2-} \quad(\mathrm{mg} / \mathrm{l})$ & $0.8 \sim 35$ & 5.5 \\
\hline 色度 (希釈倍数法) & $32 \sim 300$ & 125 \\
\hline
\end{tabular}

た後, それぞれの菌株の脱色能力を測定し, 細菌鑑定の 常用法より, 別に脱色能力の強い菌株を鑑定していた ${ }^{32}$.

4. 1.2 脱色細菌の培養

（1）培養基 ( $\mathrm{g} / \ell) \mathrm{Na}_{2} \mathrm{HPO}_{4} \cdot 12 \mathrm{H}_{2} \mathrm{O}$ （3.5）; $\mathrm{KH}_{2} \mathrm{PO}_{4}$ (1.8) ; 蛋白源（2.0）; 牛肉寒天 (3.0); 葡 萄糖（5.0）; 染料 (0.05); 蒸溜水 $1,000 \mathrm{~m} \ell ;$ PH7.0; 8 ポント滅菌 $30 \mathrm{~min}$.

(2) 細 菌 培養

牛肉汁斜面上の細菌培養物を液体培養基に移入し, 静置して, $28 \sim 30^{\circ} \mathrm{C}$ 程度の温度で, 染料の色が消され るまで培養を行った。 その後, 24時間振湯培養を続け た.このようにして実験に用いる菌種液を得た。

\section{1 . 3 実験装置}

実験装置はプレクシグラス製の反応槽で，高さ $32 \mathrm{~cm}$, 直径 $5.4 \mathrm{~cm}$, 容積 0.731 である. 反応槽には活性炭を充 填し, 充填後の有効容量が 0.421 にった。活性炭が （徐州製興華炭で）円筒型式で, 直径 $3 \sim 3.5 \mathrm{~mm}$, 高さ $3 \sim 8 \mathrm{~mm}$, 比表面積 $850 \mathrm{~m}^{2} / \mathrm{g}$ である. 充填密度が500 $\mathrm{g} / \ell$ 程度である。

4. 1.4 脱色菌生物の付着・固定

増殖培養した各脱色菌の菌液を混合して, 反応槽中 の染色廃水に投入し, 静態培養をして, 膜の付着・固 定を行った。廃水の色が除去された直後, 通気して, 培養を継続した. 同時に, 活性炭に付着している脱色 菌を増殖させるために, 少量の増殖培養基を添加した。 その後，24時間毎に上澄液の $1 / 3$ を分離させ同時に同量 の原水を加えた。活性炭上に淡灰色の生物膜が生成に なれば，通気を停止し，0.05 $\ell / h$ の流量で廃水を流 させ，5〜 7 日間の動態培養を行い，生物膜が成熟に なれば，廃水処理に用いられる。

4. 1.5 実験用廃水の水質

(1) 実験廃水の作成

実験用処理対象水は, 水道水に硫化類, 青色着色類, 活性類およびチクトール 4 種類の染料を添加すること により配製されたものである．細菌の栄養分としては，

原
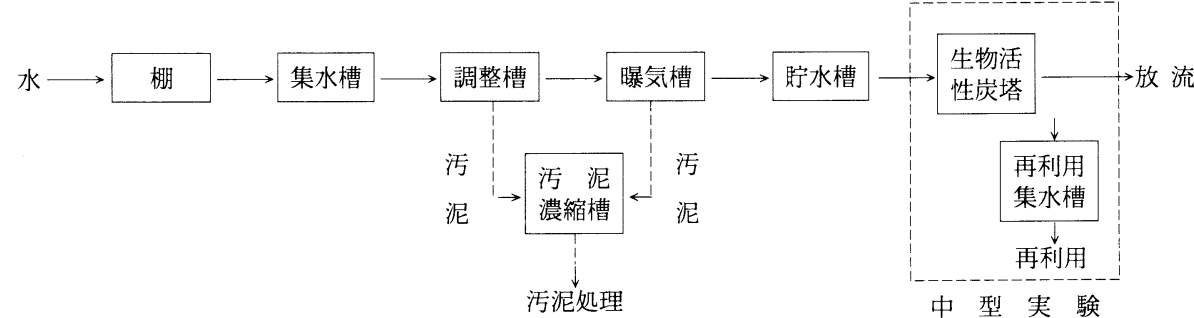

図-1 染色廃水処理フロー 
適量の蛋白寒天も添加した。作成した廃水は CODcr $150 \mathrm{mg} / \ell$, 色度64倍, pH8.02で, 大体活性污泥曝気 処理水の水質に相当している.

(2) 生産廃水

原水が活性污泥曝気で処理された後, 水質は COD cr 100 200mg / $\ell$, 色度30 70倍, pH7.0 8.5程度である.

4. 1. 6 シミュレーション

（1）活性炭生物膜処理シミュレーション実験

実験方法としては, $0.2 \ell / \mathrm{h}$ の通水速度で, 作成し た廃水を反応槽の底部にある入水口を経って, 反応室 に流入させ，上部にある出水口から流出させ，滞留時 間は 2 時間程度で, 反応温度 $28 \sim 30^{\circ} \mathrm{C} て ゙ ， 2$ 日間毎に 一回逆洗して，12日間連続運転したあのである，処理 水量が $4.8 \ell / \mathrm{d}$ 程度である.

(2) 無菌活性炭処理実験

細菌の接種, 増殖が不要, 膜の付着, 固定しなく, 無菌状態で活性炭処理実験を行った，処理対象水とし ては, $\mathrm{HgSO}_{4}$ より活性污泥曝気法の処理水を滅菌し て実験に用いた．実験条件とは，上述の(1)之同様である.

4. 1.7 分析方法

$\mathrm{K}_{2} \mathrm{C}_{\mathrm{r} 2} \mathrm{O}_{7}$ を用いて CODcr を測定した。希釈倍数 より色度を測定した。他の項目の分析については, 通 常の分析法を採用した ${ }^{5}$.

\section{2 実験結果および考察}

4. 2. 1 活性污泥に含まれた脱色菌について

分析の結果によって, 染色廃水中の活性污泥から分 離出した脱色能がある主要な菌群は Pseudomonas, Bacillus, Flavobacterium Alcaligenes Aeromonas およびAchromobacter などである.

\section{2.2 実験の結果}

染色廃水の処理効果に対して, COD と色度の除去 率が二つ重要な指標である. 表 2 に示されるように, 無菌活性炭の場合より，活性炭生物膜のほうが良好な 処理効果を示している.

2 時間程度の滞留時間では, 後者においては, C O D, 色度がいずれにも効果的に除去され，運転も安定 状態を維持していることに対して, 前者の場合には,

表 2 シミュレーション実験効果

\begin{tabular}{|c|c|c|c|c|c|c|c|c|c|}
\hline \multirow{2}{*}{\multicolumn{2}{|c|}{ 実 験 項 目 }} & \multicolumn{2}{|c|}{$\mathrm{pH}$} & \multicolumn{3}{|c|}{$\mathrm{COD}_{\alpha}(\mathrm{mg} / \ell)$} & \multicolumn{3}{|c|}{ 色 度 (倍) } \\
\hline & & 入水 & 出水 & 入水 & 出水 & 除去率 & 入水 & 出水 & 脱色 \\
\hline $\begin{array}{l}\text { 活性炭 } \\
\text { 生物膜 }\end{array}$ & $\begin{array}{c}\text { 混合染料で配製廃水 } \\
\text { 生 産 廃 水 }\end{array}$ & $\begin{array}{l}8.0 \\
7.8\end{array}$ & $\begin{array}{l}7.6 \\
7.3\end{array}$ & $\begin{array}{l}150.0 \\
143.8\end{array}$ & $\begin{array}{l}48.2 \\
43.5\end{array}$ & $\begin{array}{l}67.9 \\
69.7\end{array}$ & $\begin{array}{l}64.0 \\
48.0\end{array}$ & $\begin{array}{l}7.0 \\
4.2\end{array}$ & $\begin{array}{l}89.1 \\
91.3\end{array}$ \\
\hline $\begin{array}{l}\text { 無菌活 } \\
\text { 活生灰 }\end{array}$ & 生 産廃 水 & 7.8 & 7.8 & 143.8 & 87.5 & 39.2 & 48.0 & 30.7 & 36.0 \\
\hline
\end{tabular}

表中のデー夕は連続運転12 日間の测定值の平均值である.
その除去率が急激に低下になった。これは活性炭生物 膜が処理効果に対して，主な役割を果たしていること を明らかに表明している，その原因は，無菌活性炭の 場合，有機物に対する微生物の酸化機能がなく，活性 炭の吸着作用だけ処理機能を発揮しているものである と考えている.

4. 2. 3 細菌の脱色能力に及ぼす環境因子の影響 染色廃水の脱色は多く因子に影響されている，細菌 の種類のほか, $\mathrm{pH}$, 反応温度, 酸素などはいずれも 重要な影響因子である。そそれらの最適条件を把握する ことが染色廃水を効率的に処理することに重要である。 (1) $\mathrm{pH}$ の影響

温度 $35^{\circ} \mathrm{C}$ の条件で, $\mathrm{pH}$ を調整して, 色度 64 倍の染 色廃水の脱色実験の結果が図－2 に示されている．同 図より明らかなように, 廃水脱色における最適 $\mathrm{pH}$ 領 域は7.0 9.0. $\mathrm{pH}>9.0$ でまた $\mathrm{pH}<7.0$ の場合, 脱色 率がいずれも急激に低下している，中性，また弱アル カリ性の条件で廃水の脱色に対して最も有利であるこ とが確認できた。

(2) 温度の影響

図ー3に示しているのは, pH7.5の条件で, 反応温 度を変化させ, 染色廃水の脱色実験の結果である。こ の結果によって, 脱色における最適反応温度は $25 \sim 40{ }^{\circ} \mathrm{C}$ 範囲で, 特に $35^{\circ} \mathrm{C}$ 程度では, 最も効率的であることを 示している，温度が $20^{\circ} \mathrm{C}$ 以，または $50^{\circ} \mathrm{C}$ 以上になれ

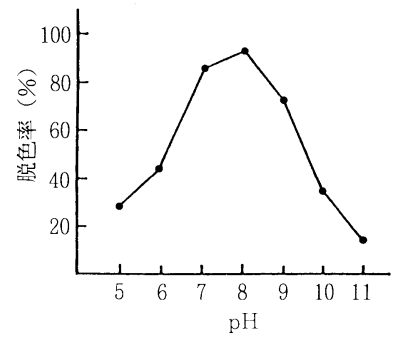

図ー2 脱色に及ぼす $\mathrm{pH}$ の影響

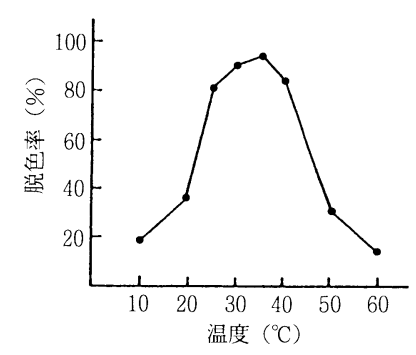

図一－脱色に及ぼす温度の影響 
表 3 脱色に及ぼす酸化の影響

\begin{tabular}{|cc|c|c|c|}
\hline \multirow{2}{*}{ 培養条件 } & \multicolumn{2}{|c|}{ 色 } & \multicolumn{1}{|c|}{ 度 } & \multirow{2}{*}{ 脱色率 (\%) } \\
\cline { 3 - 4 } & & 流入 水 & 流 出 水 & \\
\hline \multirow{2}{*}{ 静 } & 置 & 64 & 6 & 90.6 \\
通 & 気 & 64 & 28 & 56.3 \\
\hline
\end{tabular}

ば, 脱色効果が低下になる。主な原因は, 温度が $20^{\circ} \mathrm{C}$ 以下の場合, 脱色菌の活性炭を低下させ, $50^{\circ} \mathrm{C}$ 以上に なれば，脱色菌を変性失活させやすいためであると考 えている.

\section{（3）酸素の影響}

静置および通気の条件での染色廃水の脱色実験の結 果が表 3 に示されている。この結果が通気より静置の ほうが脱色効果がかなり高く, 廃水の脱色処理はある 程度の嫌気条件が必要であることを明示している。

以上述べたように，活性炭生物膜による染色廃水の 処理において, 最適 $\mathrm{pH}$ 領域は7.0 9.0で, 最適温度 範囲は $25^{\circ} \mathrm{C} \sim 40^{\circ} \mathrm{C}$ である。一方，酸素が多すぎれば廃 水の脱色に障害になり，少なすぎれば細菌の増殖に不 利であるため, 通気量の制御には注意が必要である.

\section{5. 廃水処理中型実験}

\section{1 実験装置および方法}

5. 1.1 実験装置

実験に用いた主要装置は図ー4に示すように寸法, 構造など全く同じの二つの生物活性炭塔を直列して, 連続式生物活性炭塔処理装置になるものである。塔は

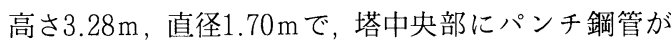
設置されている，反応室は高さ $1.92 \mathrm{~m} て ゙ ，$ 散水用パン チ鋼板より四っの分室に分割され，その上には順に

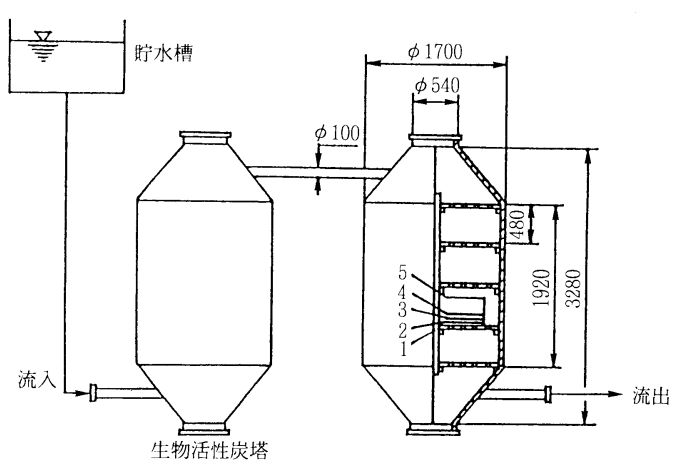

図-4 中型実験装置

1. パンチ鋼板 $2.5 \times 1(\mathrm{~mm})$ ステンレスメッシュ

3.プラスチックメッシュ 4. 活性 炭

5.鋼製パンチカバープレート ※各分室の構造が同様
$5 \times 1 （ \mathrm{~mm})$ のステンレスメッシュ, プラスチックメッ シュを敷いており，プラスチックメッシュ上に徐州製 興華活性炭 $360 \mathrm{~mm}$ の厚さで充填し, 各炭層の上に, 鋼 製パンチカバープレートを設置し，カバーと上部のパ ンチ鋼板との間隔を $100 \mathrm{~mm} \sim 120 \mathrm{~mm}$ 程度にした。このよ うにして, 活性炭層総厚さが $1.44 \mathrm{~m}$ 塔の有効容量が $4.3 \mathrm{~m}^{3} / \mathrm{d}$ になった。

さらに，中型実験が現場で実施されたので現場条件 の制約にしばられ，貯水槽の静水圧が不足のため，前 段生物活性炭塔においては下部から上向流で通水する ことに対して, 後段生物活性炭塔においては上部から 下向流で通水することにした．

5. 1.2 実験方法

（1）菌種の培養および膜の付着

脱色菌の増殖培養を行った後, 増殖した菌液を水槽 中の曝気より処理された染色廃水に移入して, 拡大培 養を継続した，窒素源と炭素源の補給として，培養液 に適量の蛋白寒天と屍房下水を加えた。 3 日間静態培 養を行った後，24時間毎に一回攪捧し，同時に適量の 旡房下水を添加した。このように繰り返して一週間の 継続培養を行った。

培養した菌液 $4 \mathrm{~m}^{3}$ を生物活性炭塔に送り，塔を一杯 にさせるまで曝気で処理された染色廃水を加えてから， 静態の条件で, 細菌の固定化, 増殖および膜の付着を 目的として，五日間の培養を行った。 その後，一日間 毎に塔中の廃水を $1 / 3$ 放流して，その代わりに，一週間 の增殖培養を続けた後, 実験に用いた。

(2) 実験フロー

運転前，処理効果を安定させるために，3 日間の連 続通水を行った。運転中，別に通気を行わず，溶存酸 素が通水に伴い補給されたものである. 実験条件とし て, 反応温度は, $30 \sim 34^{\circ} \mathrm{C}$ 程度で，通水速度は $4.4 \mathrm{~m}^{3} / \mathrm{h}$ で，滞留時間は $40 \mathrm{~min}$ (単塔に当り $20 \mathrm{~min}$ ) である. 連続運転の12日間には，一回逆洗し，逆洗速度 $8 \ell /$ $\left(\mathrm{m}^{2} ・ \mathrm{~s}\right)$ ，逆洗時間 $15 \mathrm{~min}$ である.

処理対象水は活性污泥曝気処理水で, 逆洗用水は水 道水である.

\section{2 実験結果および考察}

5. 2. 1 活性污泥曝気処理効果

表 4 は活性污泥曝気より源染色廃水の処理結果を示 している.これは任意抽出試料の分析結果で大体政府 の放流規制基準を満足しているが，循環利用水とすれ ば，その COD，色度值はまだやや高い生産再利用に 適用しにくいものである.このため, 高度処理するこ 
表 4 活性污泥曝気の処理効果

\begin{tabular}{|c|c|c|c|c|}
\hline 項 & 流入水 & 流出水 & $\begin{array}{c}\text { 除去率 } \\
\text { (\%) }\end{array}$ & $\begin{array}{l}\text { 放流規 } \\
\text { 制基準 }\end{array}$ \\
\hline 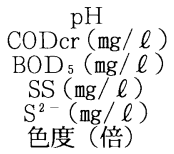 & $\begin{array}{r}9.0 \\
475.8 \\
181.2 \\
150.0 \\
7.4 \\
137.3\end{array}$ & $\begin{array}{r}7.4 \\
133.8 \\
26.8 \\
42.5 \\
1.3 \\
31.3\end{array}$ & $\begin{array}{l}71.9 \\
85.2 \\
71.7 \\
82.4 \\
77.4\end{array}$ & $\begin{array}{c}6 \sim 9 \\
180 \\
60 \\
100 \\
1.0 \\
80\end{array}$ \\
\hline
\end{tabular}

表中のデー夕は12日間の任意抽出試料の分析結果の平均值 である.

とが必要である。

5. 2.2 活性炭生物膜の処理効果

活性炭生物膜よりの高度処理結果が表 5 に 示されている，同表より明からかなように， COD, 色度の除去率で良好な処理効果を得 ている.この結果は, 活性污泥曝気処理で処 理効率の低い有機物, 染料などが活性炭生物膜に効率 的に吸着され，さらに細菌および活性炭の細孔中の胞 外エンザイムより分解され，あるいは新しい細胞に合 成されることより除去されたものを機構とすることに より説明できる。 また，その過程において，活性炭生 物膜が染色廃水の可生物化学性を大幅に高めることだ けでなく，有機物の連続分解に良好な場所も提供して いる。この機能に対して, 好気菌よりの好気分解の上 に，通性嫌気性菌および嫌気菌の嫌気分解も大きく役 割を果たしていることと推察している.

\section{6. 結語}

本研究では, 染物工場の染色廃水の COD, 色度の 除去に対する活性炭生物膜法の有効性を実験的に究明 し，その最適の条件を明らかにした。また，生物膜の 作用機能についての検討を行った．本回実験の結果と して，活性炭生物膜法を活性污泥法の次に併用する場
表 5 活性炭生物膜法の処理結果

\begin{tabular}{|c|c|c|c|c|c|c|c|c|}
\hline \multirow[b]{2}{*}{ 年月 日 } & \multicolumn{4}{|c|}{ CODcr $(\mathrm{mg} / \ell)$} & \multicolumn{4}{|c|}{ 色 度（倍） } \\
\hline & 流入水 & $\begin{array}{l}\text { 曝気槽 } \\
\text { 污流 } \\
\text { 出水 }\end{array}$ & $\begin{array}{l}\text { 生物活 } \\
\text { 性炭塔 } \\
\text { 号流 } \\
\text { 出水 }\end{array}$ & $\begin{array}{l}\text { 総除去 } \\
\text { 率 }(\%)\end{array}$ & 流入水 & $\begin{array}{l}\text { 曝気槽 } \\
\text { 加流 } \\
\text { 出水 }\end{array}$ & $\begin{array}{l}\text { 生物活 } \\
\text { 性炭塔 } \\
\text { 敌流 } \\
\text { 出水 }\end{array}$ & $\begin{array}{l}\text { 総脱色 } \\
\text { 率 }(\%)\end{array}$ \\
\hline 91.6 .3 & 557 & 166 & 47.2 & 91.5 & 256 & 32 & 4 & 98.4 \\
\hline 6.4 & 396 & 124 & 44.3 & 88.8 & 128 & 32 & 4 & 96.9 \\
\hline 6.5 & 336 & 99 & 29.5 & 91.2 & 128 & 16 & 2 & 98.4 \\
\hline 6.6 & 312 & 84 & 25.3 & 91.9 & 64 & 16 & 2 & 96.9 \\
\hline 6.7 & 498 & 118 & 43.5 & 91.3 & 128 & 32 & 4 & 96.9 \\
\hline 6.8 & 550 & 115 & 39.7 & 92.8 & 128 & 32 & 4 & 96.9 \\
\hline 6.9 & 158 & 78 & 18.2 & 88.5 & 16 & 8 & 1 & 93.8 \\
\hline 6.10 & 288 & 88 & 26.4 & 90.8 & 32 & 16 & 2 & 93.8 \\
\hline 6.11 & 776 & 239 & 79.2 & 89.8 & 256 & 64 & 8 & 96.9 \\
\hline 6.12 & 470 & 118 & 41.4 & 91.2 & 128 & 32 & 2 & 98.4 \\
\hline 6.13 & 469 & 114 & 42.6 & 90.9 & 128 & 32 & 4 & 96.9 \\
\hline 6.14 & 899 & 262 & 88.7 & 90.1 & 256 & 64 & 16 & 93.8 \\
\hline 平均値 & 475.8 & 133.8 & 43.8 & 90.8 & 137.3 & 31.3 & 4.4 & 96.8 \\
\hline
\end{tabular}

合，処理水は COD cr $<50 \mathrm{mg}$ ，平均除去率 $90.8 \%$, 色 度 $<4.5$ 倍，平均脱色率 $96.8 \%$ になり，良好な処理効果 を達成し，再利用を可能にしている。

謝辞

本研究の遂行ならびに，とりまとめにあたって，日 本国宮崎大学石黒政儀教授から終始懇切丁寧な御指導, 御鞭撻を戴きました。また同研究室に対し，ここに厚 く感謝の意を表します。

\section{参 考 文 献}

1) 北京市環境保全化学研究所編：水污染防治ハンドブック， pp388, 上海科学技術出版社, 1989 .

2）王孔星他：環境科学々技術，通巻NO49, pp 2-4，1990.

$3)$ 中国科学院微生物研究所細菌分類研究室編：細菌常用鑑 定法, 科学出版社, 北京, 1978.

4) 鮮海軍他：環境污染と防治, VOL. 10, No. 2 pp 9-13, 1988.

5 ) 中国医学科学院衛生研究所編 : 水質分析法人民衛生出版 社, 北京, 1973 .

（增補改訂版）

\section{超低周波音と低周波音}

山田伸志 (山梨大学教授) ・渡辺敏文 (福島高専助教授) ・ 小坂敏文 (東京高専助教授) 著

A 5 判 120頁 定価 $¥ 2,000$ （本体価格 $¥ 1,942 ）$

発行 環境技術研究協会 $/$ 于530 大阪市北区天満 2-1 - 20 TEL 06-357-7611 